\title{
ZAGOSPODAROWANIE TERENU ZA MURAMI RZYMSKICH FORTÓW W TAURYDZIE. NA PRZYKŁADZIE STANOWISK W BAŁAKŁAWIE-KADYKOWCE ORAZ NA PRZYLĄDKU AJ-TODOR
}

\author{
Radosław Karasiewicz-Szczypiorski \\ Uniwersytet Warszawski
}

\section{ABSTRACT
LAND MANAGEMENT BEYOND THE WALLS OF THE ROMAN FORTS IN TAURICA: A CASE OF THE SITES AT BALAKLAVA-KADYKOVKA AND ON THE AJ-TODOR CAPE}

Excavations of the remains of a Roman fort in Balaklava-Kadykovka (Sevastopol, Crimea) were conducted by researchers from the Institute of Archaeology, University of Warsaw, during 1997-1999, 2003, and 2009-2013. Various data were obtained concerning both the space within the fortification and outside it. Observation carried out on site also enriched our knowledge as to the chronology of Roman military presence in Taurica. The results of the excavations brought new perspective on the seemingly well-known Roman fort on the Aj-Todor Cape near Yalta (usually identified with Ptolemy's Charax). The forts in Balaklava-Kadykovka and on the Aj-Todor Cape were constructed by the Roman army in uninhabited areas within the Barbaricum territory. In both cases various information is available regarding the findings from beyond the walls. The analysis of these data enables a partial reconstruction of the land management in the vicinity of the forts.

Key words: Roman army, Taurica, Balaklava, Ay-Todor, Roman Fort, vicus.

Słowa kluczowe: armia rzymska, Tauryda, Bałakława, Aj-Todor, fort rzymski, vicus.

Badania nad osadnictwem i wykorzystaniem terenu za murami rzymskich fortów i obozów legionowych są prowadzone w wielu miejscach. Podobne programy badawcze realizują także polscy archeolodzy ${ }^{1}$. Zwykle chodzi o rozpoznanie terenu

1 A. Tomas, Living with the Army, 1: Civil Settlements near Roman Legionary Fortresses in Lower Moesia, Warsaw 2017; T. Sarnowski, A. Tomas, L. Kovalevskaja, P. Zakrzewski, T. Dziurdzik, E. Jęczmienowski, Novae - castra, canabae, vicus, 2013-2015. Preliminary Report on the Excava-

Adres do korespondencji: radoslaw.szczypiorski@gmail.com Instytut Archeologii UW, ul. Krakowskie Przedmieście 26/28, 06-927 Warszawa 
wokół garnizonów rozlokowanych w pobliżu granic Imperium na rzymskim terytorium. Pod tym względem rzymska obecność wojskowa w Taurydzie była wyjątkowa, ponieważ wysyłane tam oddziały (vexillationes armii dolnomezyjskiej) pozostawały formalnie na obszarze innego państwa - Chersonezu Taurydzkiego. Jeszcze bardziej wyjątkowe wydaje się położenie obu wybranych do analizy fortów, które znajdowały się poza zasięgiem chory Chersonezu, a więc de facto w Barbaricum (ryc. 1). Można w tym miejscu zaryzykować twierdzenie, że były to najdalej wysunięte garnizony rzymskie, które obsadzono w celu utrzymania pokoju poza granicami rzymskimi, a nie w związku $\mathrm{z}$ wyprawami wojennymi na teren wroga.

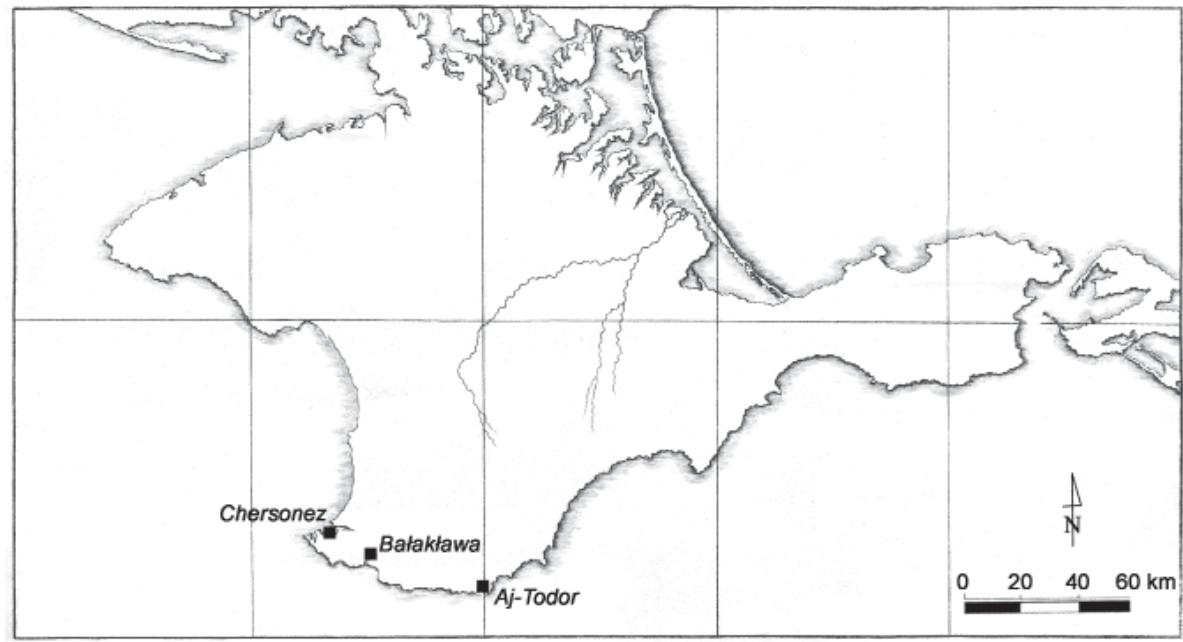

Rycina 1. Krym. Mapa przedstawiająca położenie Chersonezu Taurydzkiego oraz fortów rzymskich w Bałakławie-Kadykowce i na przylądku Aj-Todor (rys. O. Kubrak)

Wyjątkowe warunki, w których znaleźli się rzymscy żołnierze w Taurydzie, mogły mieć wpływ na sposób zagospodarowania terenu extra muros, zwłaszcza że dookoła mieszkali barbarzyńcy, a nie zromanizowana (przynajmniej częściowo) ludność z rzymskiego pogranicza. Wykopaliska prowadzone w latach 1997-1999, 2003 i 2009-2013 przez archeologów z Instytutu Archeologii Uniwersytetu Warszawskiego w Bałakławie-Kadykowce znacznie poszerzyły wiedzę na temat rzymskiego fortu i jego otoczenia² ${ }^{2}$ Uzyskane wyniki pozwoliły na nowo spojrzeć na wcześniejsze

tions and Prospection Surveys of the University of Warsaw Archaeological Expedition, „Archeologia” 2016, nr LXV, s. 198-202; A. Tomas, Canabae legionis I Italicae. State of Research on Civil Settlements Accompanying the Legionary Camp in Novae (Lower Moesia) Compared to Relevant Lower Danubian Sites, ,Światowit” 2011 (2012), nr IX (L)/A, s. 155-168.

2 T. Sarnowski, O.Ja. Savelja, Balaklava. Römische Militärstation und Heiligtum des Jupiter Dolichenus, Warschau 2000; R. Karasiewicz-Szczypiorski, Forty i posterunki rzymskie w Scytii i Taurydzie w okresie pryncypatu, „Światowit” 2015, Supplement Series A: Antiquity XV, s. 56-75, tam również pełny wykaz literatury dotyczącej badań fortu w Bałakławie-Kadykowce. 
rezultaty wykopalisk fortu na przylądku Aj-Todor (na zachód od Jałty). Porównanie dotychczasowych odkryć dokonanych na tych dwóch stanowiskach pozwala lepiej poznać organizację przestrzeni za murami fortów rozmieszczonych extra fines Imperii.

\section{CHRONOLOGIA I PERIODYZACJA OBECNOŚCI WOJSK RZYMSKICH W TAURYDZIE}

Ogromne znaczenie dla uściślenia chronologii i periodyzacji rzymskiej obecności wojskowej w Taurydzie miały polsko-ukraińskie badania świątyni Jowisza Dolicheńskiego $^{3}$ i pozostałości fortu w Bałakławie-Kadykowce ${ }^{4}$, a także wieży strażniczej na wzgórzu Kazackaja koło Inkermanu ${ }^{5}$. Dzięki tym pracom udało się skorelować kolejne fazy budowlane na wymienionych stanowiskach z tymi znanymi z wcześniejszych badań na przylądku Aj-Todor. Między innymi na podstawie wyników wymienionych badań powstały nowe zestawienia prezentujące dane na temat stacjonowania kolejnych vexillationes armii dolnomezyjskiej w Taurydzie ${ }^{6}$.

Szczególnie w przypadku fortu na przylądku Aj-Todor ewentualne pojawienie się garnizonu rzymskiego już w I wieku n.e. budzi wątpliwości badaczy ${ }^{7}$ Również na terenie Bałakławy ślady tak wczesnej obecności wojska rzymskiego są rozpoznane $\mathrm{w}$ minimalnym stopniu ${ }^{8}$. Wydaje się natomiast bardzo prawdopodobne, że w tym czasie rzymskie oddziały wysłane znad Dunaju dotarły jednak do Chersonezu?

3 T. Sarnowski, O.Ja. Savelja, Balaklava...

4 R. Karasiewicz-Szczypiorski, Forty i posterunki rzymskie...

5 T. Sarnowski, O.Ja. Savelja, R. Karasiewicz-Szczypiorski, Extra fines Imperii. Rzymski posterunek wojskowy w okolicach Sewastopola na Krymie, „Światowit” 2002, nr IV(XLV)/A, s. 167172; T. Sarnow ski, O.Ja. Savelja, R. Karasiewicz-Szczypiorski, Roman Military Sentry Posts in the Border Zone of Crimean Chersonesos, „Archeologia” 2007, nr LVIII, s. 57-67; R. Karasiewicz-Szczy piorski, Forty i posterunki rzymskie..., s. 75-82.

6 T. Sarnow ski, Römische Militärziegel von der südwestlichen Krim. Probleme der Produktionstätigkeit und Produktionsorte, „Archeologia” 2006 (2005), nr LVI, Abb. 1; R. Karasiewicz-Szczypiorski, Forty i posterunki rzymskie..., s. 174-181.

7 T. Sarnowski, The Phantom Squadron of the Ravennate Fleet on the Black Sea in the $1^{\text {st }}$ Century $A D$, „Zeitschrift für Papyrologie und Epigraphik” 2006, nr 157, s. 256-260; idem, Ti. Plautius Silvanus, Chersonesus Taurica and classis Moesica, „Dacia” 2006, nr L, s. 85-92; idem, Plavtij Silvan i eskadraprizrak na Čërnom more v I v. n.è., „Vestnik drevnej istorii” 2006, nr 1 (225), s. 117-131; idem, Römische Militärziegel..., s. 91-101; R. Karasiewicz-Szczypiorski, Forty i posterunki rzymskie..., s. $102-110$

8 R. Karasiewicz-Szczypiorski, Forty i posterunki rzymskie..., s. 59-60.

9 R.A. Gawroński, R. Karasiewicz-Szczypiorski, S. Modzelewski, The Early Empire Military Assemblages from Crimean Peninsula as Traces of Activity of the Roman Army, „Archeologia” 2014 (2011-2012), nr LXII-LXIII, s. 45-60; R.A. Gawroński, R. Karasiewicz-Szczypiorski, The Early Empire Roman Cavalry in the Defense of Tauric Chersonesus [w:] Ad fines Imperii Romanii. Studia Thaddaeo Sarnowski septuagenario ab amicis, collegis discipulisque dedicata, ed. A. Tomas, Varsaviae 2015, s. 325-340. 


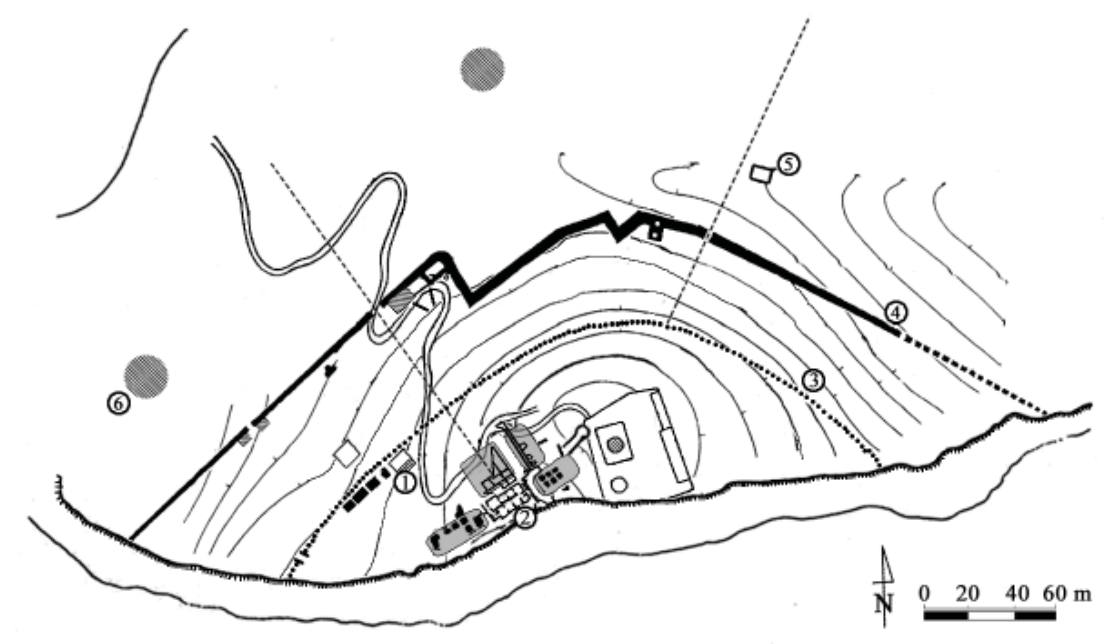

Rycina 2. Fort na przylądku Aj-Todor. Plan stanowiska: 1 - nympheum I; 2 - termy; 3 - mur wewnętrzny; 4 - mur zewnętrzny; 5 - świątynia beneficiarii; 6 - domniemana świątynia na zachód od fortu

Kompilacja wykonana na podstawie publikowanych wcześniej planów: M.I. Rostovcev", Svâtiliŝe frakijskih , bogov “ i nadpisi beneficiariev " $v$ " Aj-Todore, „Izvestiâ imperatorskoj Arheologičeskoj kommissii” 1911, nr 40, tab. 1; V.N. D' âkov, Drevnosti Aj-Todora, Âlta 1930, ryc. 7; V.D. Blavatskij, Haraks, „Materialy i issledovaniâ po arheologii SSSR” 1951, nr 19, ryc. 2;

L.V. Firsov, Izvestkovyj vâžuŝij rastvor v oboronitel'nyh stenah Haraksa (Krym), „Sovetskaâ arheologiâ" 1975, nr 1, ryc. 1; V.I Novičenkov, N.G. Novičenkova, O nižnej oboronitel'noj stene rimskoj kreposti Haraks, „Materialy po arheologii, istorii i etnografii Tavrii” 2002, nr IX, Simferopol, ryc. 3 (koncepcja - R. Karasiewicz-Szczypiorski, rys. O. Kubrak).

Nieco lepiej udokumentowana jest obecność garnizonu, w którego skład wchodzili żołnierze legionu V Macedońskiego a który pojawił się w Chersonezie najprawdopodobniej za panowania Trajana ${ }^{10}$. Ślady aktywności budowlanej pochodzące zapewne właśnie z tego okresu znajdziemy zarówno w Bałakławie-Kadykowce, jak i na przylądku Aj-Todor ${ }^{11}$. W sąsiedztwie drugiego z wymienionych fortów odkryto

10 Nagrobek żołnierza legionu V Macedońskiego: IOSPE IV 121; È.I. Solomonik, Latinskie nadpisi Hersonesa Tavričeskogo, Moskva 1983, nr 21; dachówki ze stemplami LEG V MAC i VEX LE V vex[illatio] le[gionis] $V$ [Macedonicae]: T. Sarnowski, Römische Militärziegel..., Abb. 1; R. Karasiewicz-Szczypiorski, Forty i posterunki rzymskie..., s. 175-176; ślady budowy i remontu murów Chersonezu: R. Karasiewicz-Szczy piorski, The Roman Army and the Walls of Chersonesos, „Światowit" 2014 (2013), nr XI (LII)/A, s. 93-94.

11 R. Karasiewicz-Szczypiorski, Forty i posterunki rzymskie..., s. 60-61, 106-107. 


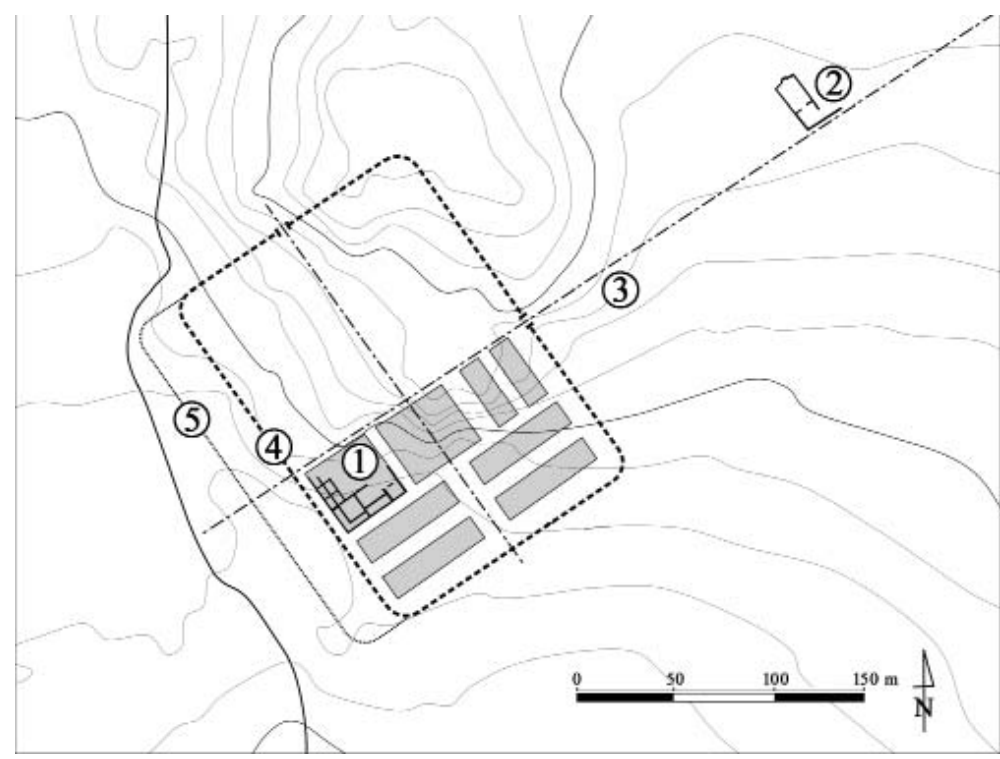

Rycina 3. Bałakława-Kadykowka. Próba rekonstrukcji planu części fortu oraz jego otoczenia: 1 - praetorium; 2 - świątynia Jowisza Dolicheńskiego; 3 - termy (lokalizacja prawdopodobna); 4 - umocnienia fortu (faza 2); 5 - prawdopodobny zasięg umocnień po rozbudowie (faza 3) (koncepcja - R. Karasiewicz-Szczypiorski, rys. J. Kaniszewski)

ponadto ołtarz poświęcony Jowiszowi ${ }^{12}$, zbudowany nie później niż w latach 20 . II wieku n.e. ${ }^{13}$

Kolejny, znacznie dłuższy i lepiej zbadany okres stacjonowania rzymskiego wojska w Taurydzie zaczął się za panowania Antoninusa Piusa i trwał pod rządami jego następców z dynastii Antoninów. W tym czasie w Bałakławie-Kadykowce i na przylądku Aj-Todor powstały forty, których pozostałości były wyraźnie uchwytne podczas wykopalisk ${ }^{14}$. W obu przypadkach umocnienia zajmowały wówczas mniejszą powierzchnię (dopiero później je rozbudowywano). Najlepiej ilustruje to przykład z drugiego z omawianych stanowisk. W drugiej połowie II wieku powstała tam jedna (później wewnętrzna) linia umocnień oraz zabudowania pod jej osłoną (ryc. 2: 3).

12 M.I. Rostovcev", Svâtilise frakijskih ,,bogov“ i nadpisi beneficiariev " ${ }^{\prime \prime}$ Aj-Todore, „Izvestiâ imperatorskoj Arheologičeskoj kommissii” 1911, nr 40, s. 5; IOSPE I² 674.

13 T. Sarnowski, Das römische Heer im Norden des Schwarzen Meeres, „Archeologia” 1989 (1987), nr XXXVIII, s. 78, tab. 3; V.M. Zubar', T. Sarnovskij, Novaâ stroitel'naâ nadpis's Aj-Todora $i$ nekotorye voprosy rimskoj voennoj organizacji v Tavrike vo vtoroj polovine II v. n.è., „Vestnik drevnej istorii” 1997, nr 4 (223), s. 54; V.M. Zubar', Rimskaâ krepost' Haraks, „Stratum Plus” 2000, nr 4: Vremâ velikih migracij, s. 192.

14 R. Karasiewicz-Szczypiorski, Forty i posterunki rzymskie..., s. 61-62, 107-108. 
Ostatni etap obecności wojskowej Rzymian, uchwytny wykopaliskowo w omawianych fortach, to okres panowania dynastii Sewerów. Zarówno w Bałakławie, jak i na przylądku Aj-Todor w tym czasie podejmowano prace budowlane, których apogeum przypadło zapewne na przełom II i III wieku. W pierwszym z wymienionych garnizonów rozbudowano praetorium (ryc. 3: 1), a teren fortu powiększono, przesuwając zachodni mur nieco dalej na dotychczasowe przedpole (ryc. 3: 5). Ślady remontu były uchwytne także w świątyni Jowisza Dolicheńskiego (ryc. 3: 2). W drugim forcie najprawdopodobniej remontowano i przebudowywano większość wcześniejszych zabudowań, w tym również termy (ryc. 2: 2). Wzniesiono także dodatkową linię umocnień - mur zewnętrzny (ryc. 2: 4). Ta rozbudowa fortyfikacji przyczyniła się do znacznego powiększenia terenu zamkniętego murami. Nie wiadomo natomiast, czy zmiany dotyczyły także świątyni beneficiarii, która pozostała na przedpolu umocnień.

\section{FORTY W TAURYDZIE: POŁOŻENIE}

W przypadku Bałakławy dzięki pomiarom wysokościowym oraz analizie wcześniejszych map oraz materiałów ilustracyjnych z okresu wojny krymskiej udało się zrekonstruować pierwotne ukształtowanie terenu. Dzięki temu wiemy, że fort był usytuowany na niewielkim wzniesieniu w widłach dwóch strumieni, w pobliżu jedynej dogodnej drogi prowadzącej z Chersonezu do Zatoki Bałakławskiej ${ }^{15}$. O przebiegu drogi także decydowało ukształtowanie terenu. Zarówno na wschód, jak i na zachód od miejsca, gdzie zbudowano fort, wznoszą się coraz wyższe wzgórza stanowiące część przedpola Gór Krymskich. Brak innych dogodnych przejść powoduje, że do dzisiaj główna droga z Sewastopola do Bałakławy przebiega niemal w tym samym miejscu.

Przylądek Aj-Todor stanowi wzniesienie odizolowane od głównego pasma Gór Krymskich. Widziany z oddali ma kształt pagórka w połowie odciętego przez morze. Najwyższy punkt znajduje się na samym brzegu - na klifie. Miejsce to stanowi doskonały punkt obserwacyjny ${ }^{16}$. Teren jest niedostępny od strony wybrzeża, ale sąsiaduje z najdogodniejszą drogą prowadzącą od zachodu do zamkniętej wysokimi górami Doliny Jałtańskiej. Stara droga biegła od wieków w sąsiedztwie fortu, w obniżeniu między przylądkiem a górami ${ }^{17}$. Wyzwaniem dla ewentualnego osadnictwa na przylądku jest przede wszystkim brak wody ${ }^{18}$. Problemem jest też bardzo źle

15 Ibidem, s. 67-69.

16 V.N. D'âkov, Drevnosti Aj-Todora, Âlta 1930, s. 7.

17 L.V. Firsov, Izvestkovyj vâžusiji rastvor v oboronitel'nyh stenah Haraksa (Krym), „Sovetskaâ arheologiâ" 1975, nr 1, s. 94.

18 A.L. Bert'e-Delagard" (A. Berthier de Lagarde), Slučajnâ̂ nahodka drevnostej bliz Âlty, „Zapiski Odesskago obŝestva istorii i drevnostej” 1907, nr XXVII, s. 25; K.K. Orlov, Arhitekturnye kompleksy Haraksa [w:] Arhitekturno-arheologičeskie issledovaniâ v Krymu, red. S.N. Bibikov, Kiev 1988, s. 22; V.M. Zubar', Rimskaâ krepost'..., s. 189. 
osłonięta naturalna przystań położona $\mathrm{w}$ szeroko otwartej zatoczce około $0,5 \mathrm{~km}$ na wschód od centrum fortu ${ }^{19}$. Berthier de Lagarde zauważył, że miejsce to ustępuje pod wieloma względami wielu innym na południowym brzegu Krymu, a dla floty wojennej lub handlowej okazuje się w ogóle nieprzydatne ${ }^{20}$. Zatoka nie chroni cumujących jednostek przed sztormem ${ }^{21}$. Wobec braku na południowym brzegu Krymu dobrych, naturalnych portów musiała jednak w tym miejscu funkcjonować przystań, którą wykorzystywano przynajmniej sezonowo. Świadczy o tym między innymi tradycyjna nazwa skały wysuniętej w morze na wschód od wspomnianej zatoczki - Liman Burun (,,skała przystani”) $)^{22}$.

O wyborze właśnie tego miejsca zdecydowało zapewne sąsiedztwo najlepszej drogi do Doliny Jałty, ale przede wszystkim rozległy widok. Przylądek umożliwiał obserwację oraz stanowił doskonały punkt nawigacyjny. Aj-Todor widać co najmniej z wysokości przylądka Ajudah (na wschodzie) aż do wysokości Skały Koszki koło współczesnego Simeizu (na zachodzie) ${ }^{23}$. O roli omawianego punktu w nawigacji wzdłuż wybrzeży Krymu świadczy też fakt, że nowożytna latarnia morska powstała w tym miejscu już w 1865 roku.

\section{FORTY W TAURYDZIE: PLAN}

Podczas wykopalisk w Bałakławie-Kadykowce udało się zaobserwować, że w fazie 2 (druga połowa II w.) umocnienia biegły równolegle do ściany praetorium położonego po przeciwnej stronie via sagularis (ryc. 3: 1, 4). Chociaż obserwacja ta została przeprowadzona na dość krótkim odcinku kurtyny muru, to jednak pozwala wysunąć hipotezę o regularnym planie fortu. Biorąc pod uwagę inne znane miejsca stacjonowania rzymskich garnizonów w Scytii i Taurydzie, byłby to pierwszy przykład budowy fortu na planie regularnym (prawdopodobnie na planie „karty do gry”).

Na przylądku Aj-Todor, mimo że Rzymianie zajęli niezagospodarowany wcześniej teren, zbudowano jednak umocnienia na nieregularnym planie. Starszy mur wewnętrzny i młodszy zewnętrzny biegną po linii przypominającej łuk. Krańce obu murów opierają się o wysoki klifowy brzeg (ryc. 2: 3,4). Dodatkowym wzmocnieniem zewnętrznej linii obrony były co najmniej dwa załomy w centralnej części kurtyny ${ }^{24}$.

19 V.M. Zubar', Rimskâa krepost'..., s. 177.

20 A.L. Bert'e-Delagard" (A. Berthier de Lagarde), op. cit., s. 25.

21 V.M. Zubar', Rimskoe voennoe prisutstve v Tavrike, ,Stratum Plus” 2001-2002 (2003), nr 4: Na okrainah antičnogo mira, s. 102-103.

22 P. Keppen, O drevnostâh" Âžnago berega Kryma i gor' Tavričeskih", „Sanktpeterburg” 1837, s. 191; V.N. D'âkov, Drevnosti..., s. 7.

23 V.N. D'âkov, Drevnosti..., s. 17; K.K. Orlov, op. cit., s. 22; V.M. Zubar', Rimskoe voennoe prisutstve..., s. 102.

24 V.I. Novičenkov, N.G. Novičenkova, O nižnej oboronitel'noj stene rimskoj kreposti Haraks, „Materialy po arheologii, istorii i etnografii Tavrii” 2002, nr IX, s. 27-35; R. Karasiewicz-Szczypiorski, Forty i posterunki rzymskie..., s. 96-99. 


\section{ŚWIĄTYNIE ZA MURAMI}

Zarówno w Bałakławie-Kadykowce, jak i na przylądku Aj-Todor za murami zostały odkryte pozostałości świątyń (ryc. 2: 5; ryc. 3: 2). W pierwszym przypadku jest to dobrze rozpoznana wykopaliskowo świątynia Jowisza Dolicheńskiego ${ }^{25}$. W drugim przypadku odkryte pozostałości świątyni nie zostały systematycznie przebadane i zadokumentowane. Przybytek jest znany w literaturze jako „świątynia beneficiarii” ze względu na fundatorów znalezionych tam ołtarzy ${ }^{26}$. Można przypuszczać, że oba miejsca kultu funkcjonowały już w początkach II wieku, to jest w okresie, w którym w Chersonezie na krótko pojawiło się vexillatio Legionu V Macedońskiego. Podczas wykopalisk w Bałakławie były uchwytne ślady użytkowania miejsca sprzed budowy świątyni datowanej na okres panowania Antoninusa Piusa ${ }^{27}$. Jeden z ołtarzy pochodzących z przylądka Aj-Todor datuje się natomiast na lata 20. II wieku, co zostało już wspomniane powyżej.

W przypadku pierwszej ze świątyń możemy stwierdzić, że była użytkowana zarówno w drugiej połowie II wieku, jak i w pierwszej połowie III wieku. Na drugim z omawianych stanowisk było najprawdopodobniej tak samo. Wskazuje na to ogólna chronologia obecności wojska rzymskiego na przylądku ${ }^{28}$. Oba wymienione miejsca kultu znajdowały się w niewielkiej odległości od umocnień przy drodze wychodzącej $\mathrm{z}$ jednej $\mathrm{z}$ bram fortu ${ }^{29}$.

Nie ma pewności, czy były to jedyne świątynie funkcjonujące za murami na omawianych stanowiskach. Niektórzy badacze sugerowali istnienie jeszcze jednego miejsca kultu na przylądku Aj-Todor (ryc. 2: 6) ${ }^{30}$. Przypuszczenie to opiera się jednak wyłącznie na podstawie luźnego znaleziska dwóch tak zwanych płytek wotywnych z przedstawieniem Artemidy. W pobliżu nie natrafiono natomiast na żadne inne zabytki ruchome ani na pozostałości architektoniczne.

Należy raczej zakładać, że w obu przypadkach za murami funkcjonowała tylko jedna świątynia, w której sprawowano różne kulty. Na takie rozwiązanie wskazują znaleziska z bałakławskiej świątyni Jowisza Dolicheńskiego, a także ze świątyni beneficiarii na przylądku Aj-Todor.

W Bałakławie obok świadectw kultu Jowisza Dolicheńskiego zostały odkryte (w całości lub w częściach) posągi, ołtarze i dekoracje rzeźbiarskie, potwierdzające oddawanie pod tym samym dachem czci także: Herkulesowi, Wulkanowi, Minerwie, Aquili (przedstawienie orła) oraz Lunie i Bakchusowi (Liber Pater). Ze względu na zły stan zachowania płyty z wyobrażeniem głowy Luny możemy się

\footnotetext{
5 T. Sarnowski, O. Ja. Savelja, Balaklava...

26 M.I. Rostovcev", op. cit., s. 5-6.

27 T. Sarnowski, O. Ja. Savelja, Balaklava..., s. 38, 57-58.

28 R. Karasiewicz-Szczypiorski, Forty i posterunki rzymskie..., s. 102-105.

29 W Bałakławie-Kadykowce było to mniej niż $100 \mathrm{~m}$, na przylądku Aj-Todor ok. $70 \mathrm{~m}$ od starszego (wewnętrznego) muru i ok. $30 \mathrm{~m}$ od młodszej (zewnętrznej) linii umocnień.

30 M.I. Rostovcev", op. cit., s. 16-17; por. V.N. D'âkov, Drevnosti..., s. 30.
} 
jedynie domyślać, że pierwotna kompozycja zawierała też przedstawienie głowy $\mathrm{Sol}^{31}$. Największe wątpliwości budzi fragment płaskorzeźby, na którym widnieje jedynie rozwiany płaszcz. Może to być pozostałość przedstawienia Mitry lub Jeźdźca Trackiego ${ }^{32}$. Co ciekawe, w Bałakławie podczas badań prowadzonych w świątyni i pobliskich zabudowaniach fortu nie natrafiono na ani jeden fragment tak zwanej płytki wotywnej. Podobne znaleziska są znane ze świątyni i fortu na przylądku Aj-Todor, a także z Chersonezu, i często bywają jednoznacznie wiązane z praktykami kultowymi rzymskiego wojska ${ }^{33}$.

Ołtarze znalezione w świątyni beneficiarii i w jej pobliżu wskazują, że głównym bóstwem czczonym obok fortu na przylądku Aj-Todor był Jowisz Kapitoliński (IOVIS Optimus Maximus). Z ruin świątyni pochodzi też zbiór 12 reliefów wotywnych lub ich fragmentów, które są identyfikowane jako ślad kultów pochodzenia trackiego ${ }^{34}$. Wspomniane reliefy wykonane w marmurze przedstawiają: Dionizosa (3 razy), Jeźdźca Trackiego (3 razy), Mitrę (2 razy), a także Hermesa, Hekate i Artemidę. Jeden relief nie został zidentyfikowany ${ }^{35}$.

W różnej odległości od świątyni beneficiarii znaleziono dwa reliefy z Artemidą (wspomniane powyżej luźne znalezisko z działki Małyszewa) oraz jedną całą płytkę i fragment innego zabytku zaliczonego do tej samej kategorii, pochodzące z różnych części fortu. Jeden $z$ tych reliefów przedstawia Jeźdźca Trackiego i jest opatrzony inskrypcją łacińską, a na drugim zapisano po łacinie grecko brzmiące imię kobiety: „[Parthe]nope" ${ }^{36}$.

\section{TERMY}

Na podstawie niemożliwych do zweryfikowania informacji uzyskanych od robotników z jednej z pobliskich budów można przypuszczać, że za murami fortu w Bałakławie-Kadykowce znajdowały się termy (ryc. 3: 3). Odkrycia dokonano przypadkiem w latach $90 . \mathrm{XX}$ wieku. Niestety znalezisko zatajono wówczas przed

31 T. Sarnowski, O. Ja. Savelja, Balaklava..., s. 71, 79, nr 16, tab. 9.1.

32 Ibidem, s. 69-70, 78, nr 6, tab. 7.6.

33 Literatura na temat znalezisk płytek wotywnych na przylądku Aj-Todor zob. przyp. 34 i 35 do niniejszego tekstu. Publikacja dotycząca płytek wotywnych z Chersonezu zob. A.N. Ŝ eglov, Frakijskie posvâtitel'nye reliefy iz Hersonesa Tavričeskogo [w:] Drevnie Frakijcy v Severnom pričernomore, red. T.D. Zlatkovskaâ, A.I. Melûkova, MIA 1969, nr 150, s. 135-177. Przeciw jednoznacznemu wiązaniu tej kategorii znalezisk z obecnością rzymskiego wojska zob. R. Karasiewicz-Szczypiorski, Forty i posterunki rzymskie..., s. 42, 100, 126-131.

${ }_{34}$ M.I. Rostovcev", op. cit., s. 1-42.

35 Ibidem, s. 13-16; por. V.N. D'âkov, Drevnosti..., s. 31; V.D. Blavatskij, Haraks, MIA 1951, nr 19, s. 251-289.

36 M.I. Rostovcev", op. cit., s. 42, nr 2; Ė.I. Solomonik, Dve slučajnye epigrafičeskie nahodki v Krymu, „Numizmatika i épigrafika” 1965, nr V, s. 97-102; K. Novychenkova-Lukychova, Ryms'ka fortecâ Haraks [w:] Roman Art and Civilization - a Common Language in Antiquity, ed. M. Iacob, Tulcea 2014, s. 140-143. 
archeologami. Na podstawie chaotycznych relacji można się jedynie domyślać, że podczas prac budowlanych uległa zniszczeniu piwnica hypokaustyczna z zachowanymi podporami (pilae) wykonanymi z cegły.

$\mathrm{Na}$ przylądku Aj-Todor termy garnizonowe to jedna z najlepiej zachowanych budowli. Obiekt został w całości przebadany, a wyniki przynajmniej części prac opublikowano ${ }^{37}$. Łaźnie były zlokalizowane wewnątrz fortu (ryc. 2: 2). Można w związku z tym przypuszczać, że nigdy nie wybudowano podobnego obiektu za murami.

\section{POZOSTAŁOŚCI INNYCH BUDOWLI}

W Bałakławie przy okazji badań świątyni Jowisza udało się ustalić, że na wschód od niej znajdował się najprawdopodobniej portyk, który mógł sąsiadować z ulicą. $\mathrm{Na}$ zachód, w stronę fortu, wykopaliska ujawniły część budynku, którego planu i przeznaczenia nie udało się zrekonstruować. Również na południe od świątyni i fortu w wykopach pod fundamenty robotnicy natrafili na warstwę kulturową i relikty murów wykonanych z takiego samego kamienia i w takiej samej technice, jak w przypadku innych budowli związanych z garnizonem rzymskim. Najpóźniejszy materiał ceramiczny we wspomnianej warstwie jest datowany na III wiek n.e. Z terenu tej budowy pochodzi również fragment dachówki ze stemplem VEMI ${ }^{38}$. Podobne stemple były częstym znaleziskiem zarówno podczas badań świątyni Jowisza, jak i pobliskiego praetorium.

\section{MIEJSCE POCHÓWKU ŻOŁNIERZY SŁUŻĄCYCH W GARNIZONIE}

Na wschód od fortu i świątyni Jowisza Dolicheńskiego w Bałakławie-Kadykowce, w pobliżu szkoły numer 33, w 1980 roku znaleziono nagrobek kawalerzysty z oddziału ala Atectorigian $a^{39}$. Podczas tych samych prac ziemnych wydobyto najprawdopodobniej także fragment drugiej steli bez zachowanych śladów napisu lub dekoracji rzeźbiarskiej. Wcześniej, przy okazji budowy wspomnianej szkoły, podobno natrafiano na pochówki szkieletowe. Jest to jednak informacja pochodząca od okolicznych mieszkańców i nie udało się jej zweryfikować. Z niepublikowanych

37 M.I. Rostowzew, Roemische Besatzungen in der Krim und das Kastell Charax, „Klio” 1902, nr 2, s. 88, fig. 1; s. 91, fig. 4 (80-95); V.D. Blavatskij, op. cit., s. 283-288.

38 Informacji na temat innych budowli sąsiadujących ze świątynią Jowisza Dolicheńskiego dotychczas nie opublikowano. Doniesienia dotyczące znalezisk związanych z obecnością rzymskiego garnizonu z terenu Bałakławy-Kadykowki zostały omówione w: R. Karasiewicz-Szczypiorski, Forty $i$ posterunki rzymskie..., s. 56-59.

39 O.Ja. Savelja, T. Sarnowski, Der Grabstein des Iulius Valens aus Balaklava [w:] eidem, Balaklava..., s. 191-196. 
danych zgromadzonych przez O. Sawelję wynika natomiast, że pojedynczy grób został odkryty przypadkowo podczas sadzenia krzewów przy budynku szkoły w roku 1990. Znaleziono wówczas szkielet bez wyposażenia, zorientowany głową na zachód. Badacz powątpiewał jednak, czy ten pochówek można wiązać z okresem rzymskim. Jego zdaniem był to najprawdopodobniej grób z XVIII lub XIX wieku.

Również w pobliżu fortu na przylądku Aj-Todor musiało się znajdować miejsce pochówku wykorzystywane przez rzymskie wojsko. Dotychczasowe wykopaliska przyczyniły się tylko do odkrycia cmentarzyska ciałopalnego datowanego na III-IV wiek $^{40}$. Nie natrafiono na wcześniejsze pochówki. Jedyny materialny ślad cmentarza, który powinien funkcjonować, dopóki w forcie stacjonował rzymski garnizon, to najprawdopodobniej kamień nagrobny z przedstawieniem jeźdźca i z łacińską inskryp$\mathrm{cją}^{41}$. Podobnie jak w przypadku nagrobka kawalerzysty z Bałakławy-Kadykowki, dysponujemy tylko tym jednym materialnym śladem cmentarza przy forcie ${ }^{42}, \mathrm{z}$ tym że w Bałakławie jest znane miejsce znalezienia steli i można przypuszczać, że została ona odkryta in $s i t u^{43}$. Pochodzenie nagrobka wiązanego z przylądkiem Aj-Todor jest natomiast niepewne. W literaturze pojawia się opinia, że zabytek został nabyty w XIX wieku do kolekcji Woroncowów (być może w Rzymie) wraz z innymi przedmiotami ${ }^{44}$. Bardziej prawdopodobne wydaje się jednak, że trafił do pałacu w Ałupce w wyniku wykopalisk, które na przylądku Aj-Todor prowadził zięć właściciela zbiorów - hrabia Szuwałow ${ }^{45}$.

\section{DOSTARCZANIE WODY}

W Bałakławie nie natrafiono dotychczas na pozostałości wodociągu. Można jednak przypuszczać, że w forcie i towarzyszącym osiedlu woda $\mathrm{z}$ dwóch płynących w pobliżu strumieni zaspokajała wszystkie potrzeby garnizonu i cywilnej osady. $\mathrm{Na}$ przylądku Aj-Todor i w jego pobliżu brak jakichkolwiek źródeł wody. W tym przypadku problem mogła rozwiązać tylko budowa akweduktu. Poza fortem znaleziono dotychczas fragment jednego wodociągu $\mathrm{z}$ rur ceramicznych. Biegnie on od strony źródła bijącego do dziś na stokach Aj-Petri. Akwedukt odkryto około $700 \mathrm{~m}$ od położonego wewnątrz umocnień nympheum I, do którego zapewne prowadzi14 ${ }^{46}$. Powstanie wodociągu można najprawdopodobniej datować na II wiek ${ }^{47}$.

\footnotetext{
40 V.D. Blavatskij, op. cit., s. 262-274, 291.

41 M.I. Rostovcev", op. cit., s. 38, tabl. III; V.N. D’âkov, Drevnosti..., s. 4; AÉ 1990: 871.

42 O.Ja. Savelj a, T. Sarnowski, Der Grabstein... s. 191-196.

43 R. Karasiewicz-Szczypiorski, Forty i posterunki rzymskie..., s. 56.

44 M.I. Rostovcev", op. cit., s. 38.

45 V.N. D'âkov, Drevnosti..., s. 6.

46 V.D. Blavatskij, op. cit., s. 260, 288, ryc. 24: 6; K.K. Orlov, op. cit., s. 21.

47 V.D. Blavatskij, op. cit., s. 289.
} 


\section{PRODUKCJA CERAMICZNA ZA MURAMI}

W Bałakławie-Kadykowce w odległości około 350 m na północny wschód od fortu znajduje się złoże dobrej gliny, które jeszcze w drugiej połowie XX wieku było wykorzystywane przez lokalne zakłady ceramiczne. Podczas badań na tym stanowisku znajdowano wybrakowane egzemplarze dachówek. Wykorzystywanie wadliwego produktu świadczy pośrednio o wytwarzaniu go gdzieś w pobliżu. Nie było powodu, aby dostarczać taki materiał na odległe place budowy. To przypuszczenie znalazło potwierdzenie w wynikach badań fizykochemicznych surowej gliny oraz próbek pochodzących z sygnowanej ceramiki budowlanej. Próbki pochodziły ze stanowisk związanych z rzymską obecnością wojskową na Krymie ${ }^{48}$. Na tej podstawie można stwierdzić, że przynajmniej część materiałów budowlanych wykorzystywanych przez rzymskie garnizony w Taurydzie wytwarzano w cegielni bałakławskiego garnizonu.

Wobec przytoczonych powyżej wyników badań można przypuszczać, że nie było potrzeby produkowania ceramiki budowlanej także na przylądku Aj-Todor. Kilka faktów wskazuje jednak, że przynajmniej okresowo również ten fort uruchamiał własną cegielnię.

Także tu znajduje się dobre złoże gliny, znane od pokoleń i nazywane, ,gliniankąa"49. Ponadto na zachód od przylądka, podczas budowy domu wielkiego księcia Aleksandra Michaiłowicza Romanowa, odkryto duży depozyt rozbitych wyrobów ceramicznych. Niestety brak informacji, jak datowano to znalezisko ${ }^{50}$.

Wspomniane wysypisko „braku” produkcyjnego stanowi dowód faktycznego funkcjonowania w pobliżu wytwórni ceramiki. Nie wiemy jednak, czy znaleziono tam także wybrakowaną ceramikę budowlaną i czy depozyt można datować na pierwsze wieki n.e.

Berthier de Lagarde (podobnie jak inni badacze) podkreślał zupełny brak wody w najbliższej okolicy ${ }^{51}$. Była to chyba główna przyczyna braku aktywności osadniczej od schyłku okresu rzymskiego po czasy nowożytne. Można zatem przypuszczać, ze zbudowany przez Rzymian wodociąg funkcjonował tylko do czasu opuszczenia fortu, a więc najpóźniej do połowy III wieku ${ }^{52}$. Na tej podstawie można wnioskować, że produkcja ceramiczna rozwijała się w okolicy przylądka tylko w okresie stacjonowania rzymskiego garnizonu. Pośrednio wskazuje na to także znalezienie wspomnianego wysypiska po produkcji ceramicznej na terenie, przez który przebiegał akwedukt, czyli na zachód od fortu.

48 T. Sarnow ski, Römische Militärziegel...

49 A.L. Bert'e-Delagard" (A. Berthier de Lagarde), op. cit., s. 25; V.N. D'âkov, Drevnosti..., s. 29.

50 A.L. Bert'e-Delagard" (A. Berthier de Lagarde), op. cit., s. 25; V.N. D'âkov, Drevnosti..., s. 29; K.K. Orlov, op. cit., s. 21.

${ }_{51}$ A.L. Bert'e-Delagard" (A. Berthier de Lagarde), op. cit., s. 25; K.K. Orlov, op. cit., s. 22; V.M. Zubar', Rimskaâ krepost'...s. 189.

52 K.K. Orlov, op. cit., s. 22, 27; V.M. Zubar', Rimskaâ krepost'..., s. 198. 
Dodatkowym argumentem na rzecz istnienia odrębnej cegielni jest także występowanie na ceramice budowlanej znajdowanej na przylądku typów stempli nieznanych $\mathrm{z}$ innych miejsc stacjonowania vexillationes armii dolnomezyjskiej w Taurydzie ${ }^{53}$.

\section{DROGA W SĄSIEDZTWIE FORTU}

Jak wspomniano powyżej, oba forty zostały wzniesione w bezpośrednim sąsiedztwie głównej drogi. W przypadku Bałakławy-Kadykowki droga łączyła Chersonez $\mathrm{i}$ jego terytorium wiejskie $\mathrm{z}$ doskonałym naturalnym portem w Zatoce Bałakławskiej. Można być niemal pewnym, że wspomniany port stanowił ważną przystań na szlaku rzymskich okrętów wojennych i statków z zaopatrzeniem. Droga przebiegała najprawdopodobniej na wschód od fortu, przechodząc w bezpośrednim sąsiedztwie świątyni Jowisza Dolicheńskiego. Wskazują na to zachowane źródła ikonograficzne i kartograficzne z okresu wojny krymskiej oraz analiza zrekonstruowanej rzeźby terenu ${ }^{54}$.

Po odkryciu na przylądku Aj-Todor świątyni za murami i ołtarzy ufundowanych przez beneficiarii Roztowcew uznał, że miejsce kultu mogło być powiązane z posterunkiem wojskowym przy ważnym szlaku lub skrzyżowaniu dróg ${ }^{55}$. Od tego czasu część badaczy zakłada, że obok fortu biegła ważna droga, która mogła łączyć południowe wybrzeże Taurydy z Chersonezem ${ }^{56}$.

Jak wspomniano powyżej, fort na przylądku Aj-Todor został wzniesiony w sąsiedztwie najdogodniejszego naturalnego przejścia na teren Doliny Jałtańskiej. Piszący te słowa nie jest jednak przekonany, czy biegnąca z zachodu droga była zbudowanym i strzeżonym przez rzymskie wojsko traktem zapewniającym stałe połączenie z Chersonezem. Trzeba mieć na uwadze, że szlak przez góry był długi i niewygodny, a jego utrzymanie i kontrolowanie musiałoby przekraczać możliwości oddalonych od siebie garnizonów w Bałakławie-Kadykowce oraz na przylądku Aj-Todor. Wydaje się niemal pewne, że mimo niedogodnej przystani ${ }^{57}$ zaopatrzenie dla fortu było jednak dostarczane morzem. Droga lądowa miała najprawdopodobniej minimalne znaczenie dla transportu organizowanego przez rzymskie wojsko. Jej rola mogła wzrosnąć w czasach późniejszych. Większość śladów okolicznych osad jest datowana

53 T. Sarnowski, Römische Militärziegel..., Abb. 1; R. Karasiewicz-Szczypiorski, Forty i posterunki rzymskie..., s. 175.

54 R. Karasiewicz-Szczypiorski, Forty i posterunki rzymskie..., s. 67-70.

55 M.I. Rostovcev", op. cit., s. 7, 9.

56 V.N. D’âkov, Tavrika v epoku rimskoj okkupacii, „Učënye zapiski Moskovskogo gosudarstvennogo pedagogičeskogo instituta" 1942, nr XXVIII, s. 80; K.K. Orlov, op. cit., s. 21.

57 A.L. Bert'e-Delagard"(A. Berthier de Lagarde), op. cit., s. 25. 
dopiero na okres średniowiecza ${ }^{58}$. Również miasta na południowym brzegu Krymu (np. Aluston) powstawały najwcześniej w VI wieku ${ }^{59}$.

Sięgając po argumenty bliższe współczesności, warto zauważyć, że tradycyjną trasą (od strony Sewastopola przez Przełęcz Bajdarską) trafił na południowy brzeg między innymi Adam Mickiewicz. Dowód na to stanowi choćby tematyka kolejnych Sonetów krymskich. Mimo to nawet w okresie późniejszym droga prowadząca do Jałty z zachodu była na mapach oznaczona jako podrzędny szlak. Jeszcze w początkach $\mathrm{XX}$ wieku rodzina carska dojeżdżała z Petersburga do Sewastopola pociągiem, ale dalej do pałacu w Liwadii była dowożona morzem! ${ }^{60}$

Wobec wielu wątpliwości co do potrzeby istnienia i jakości szlaku lądowego, który przebiegał obok przylądka, można zakładać, że wojsko z fortu kontrolowało raczej ruch lokalnej ludności zmierzającej do Doliny Jałtańskiej niż jakieś kolumny rzymskiego wojska lub konwoje z zaopatrzeniem. Podstawową przyczyną budowy fortu rzymskiego w tym izolowanym miejscu było jednak najprawdopodobniej zapewnienie bezpieczeństwa na szlaku żeglugowym.

\section{POŁOŻENIE OSADY ZA MURAMI}

W Bałakławie-Kadykowce na miejsce, w którym znajdowała się osada za murami (vicus), wskazują między innymi: ukształtowanie terenu, najbardziej prawdopodobny przebieg starego szlaku do portu w Zatoce Bałakławskiej oraz położenie świątyni Jowisza Dolicheńskiego i innych budowli, których pozostałości odkrywano w pobliżu (ryc. 3: 2, 3). Zgromadzone informacje pozwalają się domyślać, że wspomniana osada mieściła się na wschód od fortu, w niewielkim obniżeniu terenu. Na wzniesieniu, na przeciwległym (wschodnim) krańcu tej kotliny, znajdował się cmentarz. Wspomniana świątynia była położona w granicach osady, być może przy skrzyżowaniu głównych dróg biegnących pośród zabudowań.

Większość uczonych prowadzących badania na stanowisku Aj-Todor sugerowała istnienie osady za murami ${ }^{61}$. Orłow podkreślał natomiast, że w sąsiedztwie fortu dotychczas nie odkryto śladów warstwy kulturowej, której grubość i zasięg sugerowałyby stabilne osadnictwo ${ }^{62}$. Zubar również twierdził, że za jest wcześnie, aby mówić o istnieniu osady przyobozowej ${ }^{63}$.

58 K.K. Orlov, op. cit., s. 18; por. D'âkov, Drevnosti..., s. 18.

59 V.L. Myc, Rannij etap stroitelstva kreposti Aluston [w:] Alušta i Aluštinskij region, red. V.L. Myc et al., Kiev 2002, s. 16.

60 R. Karasiewicz-Szczypiorski, Forty i posterunki rzymskie..., s. 102.

${ }_{61}$ M.I. Rostovcev", Rimskie garnizony na Tavričeskom poluostrove i Aj-Todorskaâ krepost', „Žurnal Ministerstva narodnogo prosveŝeniâ" 1900, nr 308, s. 152; M.I. Ro stovcev", op. cit., s. 35, 41; V.N. D'âkov, Drevnosti..., s. 29-31; V.N. D'âkov, Tavrika..., s. 75; V.D. Blavatskij, op. cit., s. 290.

62 K.K. Orlov, op. cit., s. 21.

63 V.M. Zubar', Rimskaâ krepost'..., s. 197. 
W przypadku fortu na przylądku dysponujemy znacznie mniejszym zasobem informacji, które mogą się okazać pomocne przy określeniu położenia podobnej osady. Odnosząc się do sytuacji znanej z Bałakławy, należy przede wszystkim zwrócić uwagę na świątynię beneficiarii (ryc. 2: 5) położoną za murami, w niewielkiej odległości od jednej z bram w zewnętrznej linii umocnień. Przez to przejście wychodziła droga prowadząca na północny wschód, między innymi do pobliskiej przystani. Domniemane osiedle mogło zajmować teren w pobliżu świątyni, przy wspomnianej drodze. Nie wydaje się natomiast, aby bezpośredni związek z osadą miały ślady produkcji ceramicznej, na które natrafiono na zachód od fortu. O wyborze miejsca, gdzie produkowano ceramikę, z pewnością decydowały przede wszystkim sąsiedztwo złoża gliny i dostęp do wody. W Bałakławie-Kadykowce cegielnia garnizonowa była najprawdopodobniej również oddalona o kilkaset metrów od umocnień i towarzyszącego osiedla.

\section{PROBLEM ZAMIESZKIWANIA RZYMSKICH CYWILÓW EXTRA MUROS}

Jeden z ołtarzy znalezionych w Bałakławie-Kadykowce został wystawiony Wulkanowi przez centuriona Antoniusza Proculusa z legionu XI Klaudiuszowego ${ }^{64}$. Podoficer ten niemal na pewno służył w miejscowym garnizonie. Z innej inskrypcji znalezionej w Chersonezie ${ }^{65}$ dowiadujemy się, że jego żona i co najmniej jedna córka zamieszkiwały w tym mieście. Wskazuje na to fakt, że wspomniane dziecko zostało tam pochowane ${ }^{66}$. Przytoczone źródła dowodzą, że w przypadku Bałakławy, położonej zaledwie kilkanaście kilometrów od Chersonezu, przynajmniej okresowo rodziny wojskowych mogły zamieszkiwać w mieście. Jednocześnie dysponujemy jednak wynikami wykopalisk, które potwierdzają istnienie osiedla na wschód od fortu.

Na przylądku Aj-Todor źródła archeologiczne przynoszą nam znacznie mniej informacji. W kwestii ewentualnego zamieszkiwania rodzin wojskowych i związanych z garnizonem cywilów na przylądku nieco więcej danych uzyskujemy dzięki innym kategoriom znalezisk, w tym źródłom epigraficznym.

Podczas wykopalisk na terenie fortu znaleziono fragment reliefu wotywnego z żeńskim imieniem [Parthe]nope ${ }^{67}$. Przypuszczenia dotyczące obecności cywilów związanych z garnizonem można także opierać na interpretacji znalezisk reliefów wotywnych z Chersonezu. Rozproszenie tych przedmiotów po różnych dzielnicach miasta (niemal wyłącznie poza cytadelą, gdzie stacjonował rzymski garnizon) stanowi jeden z argumentów na rzecz hipotezy o stałym zamieszkiwaniu w mieście gru-

${ }_{64}$ T. Sarnowski, O.Ja. Savelja, Balaklava..., s. 88-89, nr 27.

${ }_{65}$ È.I. Solomonik, Novye èpigrafičeskie pamâtniki Hersonesa, Kiev 1964, nr 65; AÉ 1967: nr 435; È.I. Solomonik, Latinskie nadpisi..., nr 24.

66 T. Sarnowski, O.Ja. Savelja, Zu den Familienverhältnissen der römischen Soldaten und Offiziere auf der Südkrim [w:] eidem, Balaklava ..., s. 197-200.

67 M.I. Rostovcev", op. cit., s. 42; V.M. Zubar', Rimskaâ krepost'..., s. 197. 
py cywilów, zapewne pochodzących głównie z bałkańskich prowincji Imperium ${ }^{68}$. W związku ze znaleziskami z przylądka Aj-Todor, pochodzącymi głównie ze świątyni za murami, pojawiały się sugestie, że przybytek służył nie tylko żołnierzom, ale również ludności cywilnej ${ }^{69}$. Może więc jednak reliefy wotywne nie powinny być traktowane jak świadectwo kultów sprawowanych wyłącznie przez żołnierzy?

Szukając śladów pobytu cywilów, a tym samym argumentów na rzecz istnienia osiedla przyobozowego na przylądku Aj-Todor, warto także zwrócić uwagę na ołtarze pochodzące ze świątyni beneficiarii. Jeden z ołtarzy ${ }^{70}$ wystawił beneficiarius consularis z legionu XI Klaudiuszowego „pro sa[1(ute)] sua et filiorum ....”. Wystawcą kolejnego ołtarza był inny beneficiarius consularis, a napis na zabytku zawiera formułę ,pro sal(ute) sua et su[or(um)]"71. Fundowanie wotów także w imieniu bliskich może (ale nie musi) świadczyć, że te osoby cywilne przybyły wraz z beneficiarii do Taurydy. Nie można oczywiście stwierdzić, czy dotarły aż na przylądek Aj-Todor, a jeśli tak, to czy mieszkały extra czy może jednak intra muros. Opisany powyżej przykład centuriona Antoniusza Proculusa, także z legionu XI Klaudiuszowego, nie pozwala jednak na rozstrzygnięcie tej kwestii.

Na podstawie zgromadzonych dotychczas informacji nie można jednoznacznie stwierdzić, czy bliscy oficerów rzymskich, którzy przybywali na południowy brzeg Krymu, także zamieszkiwali na przylądku Aj-Todor.

\section{WNIOSKI}

Zebrane i przedstawione powyżej informacje pozwalają zrekonstruować w zarysie położenie osiedli za murami, które towarzyszyły fortom rzymskim w Taurydzie. Prowadzone przez wiele lat wykopaliska nie dają odpowiedzi na wiele pytań dotyczących planu osad oraz liczby i przeznaczenia funkcjonujących w ich ramach budowli. Można jednak uchwycić pewne różnice i podobieństwa pomiędzy prezentowanymi stanowiskami.

Zarówno w Bałakławie-Kadykowce, jak i na przylądku Aj-Todor poza murami fortu znajdowała się świątynia. Na podstawie wyników badań, przede wszystkim z pierwszego z wymienionych stanowisk, można przypuszczać, że w obu przypadkach była to jedyna świątynia w osadzie. $Z$ jej wnętrza korzystali wyznawcy różnych kultów. Nie ma jednak pewności, czy tylko żołnierze, czy także cywile. Oba przybytki były zlokalizowane przy jednej z głównych dróg - przy ulicy wychodzącej z jednej z bram pobliskiego fortu. Różny jest dobór bóstw, którym oddawano cześć i wystawiano wota w każdej ze świątyń. Szczególnie znamienny wydaje się brak w Bałakławie reliefów wotywnych, których znaczny zbiór pochodzi z przybytku

\footnotetext{
68 R. Karasiewicz-Szczypiorski, Forty i posterunki rzymskie..., s. 42.

69 V.N. D'âkov, Drevnosti..., s. 31-32.

70 M.I. Rostovcev", op. cit., s. 5, nr 2; IOSPE I² 675.

71 M.I. Rostovcev", op. cit., s. 6, nr 3; IOSPE I² 676.
} 
i fortu na przylądku. Być może jest to ślad różnego pochodzenia żołnierzy wchodzących w skład vexillationes stacjonujących w każdym z garnizonów.

Produkcja ceramiki budowlanej w pobliżu fortu została potwierdzona w przypad$\mathrm{ku}$ Bałakławy. Materiały budowlane z tej wytwórni wykorzystywano także na innych placach budów prowadzonych przez rzymskie wojsko w Taurydzie. Mimo to są podstawy, aby przypuszczać, że także na przylądku Aj-Todor (przynajmniej okresowo) funkcjonowała cegielnia. Uruchomienie własnej wytwórni mogło być spowodowane znaczną odległością od Bałakławy i izolacją garnizonu na przylądku od innych miejsc stacjonowania oddziałów rzymskich.

Wspomniana izolacja mogła mieć też wpływ na decyzję o ewentualnym sprowadzeniu rodzin oficerów. Zgromadzone informacje nie pozwalają rozstrzygnąć, czy wymieniani w inskrypcjach na ołtarzach bliscy fundatorów przebywali na miejscu, czy może mieszkali w Chersonezie, tak jak to było w jednym udokumentowanym przykładzie z Bałakławy.

W pobliżu obu fortów musiały się także znajdować cmentarze, na których grzebano zmarłych żołnierzy oraz związanych z garnizonem cywilów. W przypadku Bałakławy mamy podstawy, aby wskazywać konkretne miejsce ich pochówku. Na przylądku Aj-Todor analogiczne miejsce grzebalne nie zostało dotychczas odkryte.

Wydaje się, że o pewnych różnicach w zagospodarowaniu terenu za murami w obu omawianych przypadkach świadczy między innymi lokalizacja łaźni. W Bałakławie termy zbudowano najprawdopodobniej poza murami, w granicach osady przyobozowej. Na przylądku Aj-Todor łaźnia znajdowała się wewnątrz fortu.

Podsumowując powyższe rozważania, można wysunąć przypuszczenie, że położona bliżej Chersonezu Bałakława zapewniała lepsze warunki do rozwoju osadnictwa w sąsiedztwie garnizonu. Potwierdzają to także wyniki badań powierzchniowych prowadzonych przez piszącego te słowa w pobliskiej Dolinie Bałakławskiej. Wspomniane badania wykazały wzrost aktywności osadniczej w okolicy Bałakławy w okresie stacjonowania rzymskiego wojska ${ }^{72}$. W innej sytuacji znajdował się garnizon na przylądku Aj-Todor. Oddalony od pozostałych rzymskich placówek stanowił izolowaną wojskową enklawę na terenie Barbaricum. Na zmniejszone poczucie bezpieczeństwa wskazuje budowa i późniejsza rozbudowa term wewnątrz fortu. Można zatem przypuszczać, że ewentualne osiedle za murami na przylądku mogło być znacznie mniejsze niż w Bałakławie.

Wiele pytań zapewne długo pozostanie bez odpowiedzi. Kontynuacji badań na obu omawianych stanowiskach nie sprzyja ani postępująca zabudowa części ich obszaru (dotyczy to szczególnie Bałakławy), ani aktualna sytuacja polityczna.

72 R. Karasiewicz-Szczypiorski, Forty i posterunki rzymskie..., s. 169, 173. 


\section{SKRÓTY BIBLIOGRAFICZNE}

AÉ - L’Année épigraphique, Paris.

IOSPE I$^{2}-$ B. Latyschev, Inscriptiones antiquae Orae Septentrionalis Ponti Euxini. Inscriptiones Tyrae, Olbiae, Chersonesi Tauricae aliorum locorum a Danubio usque ad regnum Bosporanum, Petropoli 1916.

IOSPE IV - B. Latyschev, Inscriptiones antiquae Orae Septentrionalis Ponti Euxini. Graece et latinae per annos 1885-1900 repertae, Hildesheim 1965.

MIA - „Materialy i issledovaniâ po arheologii SSSR”

\section{BIBLIOGRAFIA}

Bert'e-Delagard" A.L. (A. Berthier de Lagarde), Slučajnaâ nahodka drevnostej bliz Alty, „Zapiski Odesskago obŝestva istorii i drevnostej” 1907, nr XXVII, s. 19-27.

Blavatskij V.D., Haraks, „Materialy i issledovaniâ po archeologii SSSR” 1951, nr 19, S. 251-289.

D’âkov V.N., Drevnosti Aj-Todora, Âlta 1930.

D’âkov V.N., Tavrika v epoku rimskoj okkupacii, „Učënye zapiski Moskovskogo gosudarstvennogo pedagogičeskogo instituta" 1942, nr XXVIII.

Firsov L.V., Izvestkovyj vâžusiji rastvor v oboronitel'nyh stenah Haraksa (Krym), „Sovetskaâ arheologiâ" 1975, nr 1, s. 94-101.

Gawroński R.A., Karasiewicz-Szczypiorski R., The Early Empire Roman Cavalry in the Defense of Tauric Chersonesus [w:] Ad fines Imperii Romanii. Studia Thaddaeo Sarnowski septuagenario ab amicis, collegis discipulisque dedicata, ed. A. Tomas, Varsaviae 2015, s. 325-340.

Gawroński R.A., Karasiewicz-Szczypiorski R., Modzelewski S., The Early Empire Military Assemblages from Crimean Peninsula as Traces of Activity of the Roman Army, „Archeologia” 2014 (2011-2012), nr LXII-LXIII, s. 45-60.

Karasiewicz-Szczypiorski R., Forty i posterunki rzymskie w Scytii i Taurydzie w okresie pryncypatu, „Światowit” 2015, Supplement Series A: Antiquity XV.

Karasiewicz-Szczypiorski R., The Roman Army and the Walls of Chersonesos, „Światowit” 2014 (2013), nr XI (LII)/A, s. 87-112.

Keppen P., O drevnostâh" ûžnago berega Kryma i gor' Tavričeskih", „Sanktpeterburg” 1837.

Myc V.L., Rannij etap stroitelstva kreposti Aluston [w:] Alušta i Aluštinskij region, red. V.L. Myc et al., Kiev 2002, s. 16-29.

Novičenkov V.I., Novičenkova N.G., O nižnej oboronitel'noj stene rimskoj kreposti Haraks, „Materialy po arheologii, istorii i etnografii Tavrii” 2002, nr IX, s. 27-35.

Novychenkova-Lukychova K., Ryms'ka fortecâ Haraks [w:] Roman Art and Civilization - a Common Language in Antiquity, ed. M. Iacob, Tulcea 2014, s. 140-143.

Orlov K.K., Arhitekturnye kompleksy Haraksa [w:] Arhitekturno-arheologičeskie issledovaniâ v Krymu, red. S.N. Bibikov, Kiev 1988, s. 16-27. 
Rostowzew M.I., Roemische Besatzungen in der Krim und das Kastell Charax, „Klio” 1902, nr 2, s. 80-95.

Rostovcev" M.I. Rimskie garnizony na Tavričeskom poluostrove i Aj-Todorskaâ krepost', „Žurnal Ministerstva narodnogo prosveŝeniâ" 1900, nr 308, s. 140-158.

Rostovcev" M.I., Svâtiliŝe frakijskih ,, bogov“ i nadpisi beneficiariev "v" Aj-Todore, „Izvestiâ imperatorskoj arheologičeskoj kommissii” 1911, nr 40, s. 1-42.

Sarnowski T., The Phantom Squadron of the Ravennate Fleet on the Black Sea in the $1^{\text {st }}$ Century AD, ,Zeitschrift für Papyrologie und Epigraphik” 2006, nr 157, s. 256-260.

Sarnowski T., Plavtij Silvan i eskadra-prizrak na Čërnom more v I v. n.è., ,,Vestnik drevnej istorii” 2006, nr 1 (225), s. 117-131.

Sarnowski T., Das römische Heer im Norden des Schwarzen Meeres, „Archeologia” 1989 (1987), nr XXXVIII, s. 61-98.

Sarnowski T., Römische Militärziegel von der südwestlichen Krim. Probleme der Produktionstätigkeit und Produktionsorte, „Archeologia” 2006 (2005), nr LVI, s. 91-101.

Sarnowski T., Ti. Plautius Silvanus, Chersonesus Taurica and classis Moesica, „Dacia” 2006, nr L, s. 85-92.

Sarnowski T., Savelja O.Ja., Balaklava. Römische Militärstation und Heiligtum des Jupiter Dolichenus, Warschau 2000.

Sarnowski T., Savelja O.Ja., Zu den Familienverhältnissen der römischen Soldaten und Offiziere auf der Südkrim [w:] Balaklava. Römische Militärstation und Heiligtum des Jupiter Dolichenus, Hrsg. T. Sarnowski, O.Ja. Savelja, Warschau 2000, s. 197-200.

Sarnowski T., Savelja O.Ja., Karasiewicz-Szczypiorski R., Extra fines Imperii. Rzymski posterunek wojskowy w okolicach Sewastopola na Krymie, „Światowit” 2002, $\mathrm{nr} \operatorname{IV}(\mathrm{XLV}) / \mathrm{A}$, s. 167-172.

Sarnowski T., Savelja O.Ja., Karasiewicz-Szczypiorski R., Roman Military Sentry Posts in the Border Zone of Crimean Chersonesos, „Archeologia” 2007, nr LVIII, s. $57-67$.

Sarnowski T., Tomas A., Kovalevskaja L., Zakrzewski P., Dziurdzik T., Jęczmienow ski E., Novae - castra, canabae, vicus, 2013-2015. Preliminary Report on the Excavations and Prospection Surveys of the University of Warsaw Archaeological Expedition, „Archeologia” 2016, nr LXV, s. 177-203.

Savelja O.Ja., Sarnowski T., Der Grabstein des Iulius Valens aus Balaklava [w:] Balaklava. Römische Militärstation und Heiligtum des Jupiter Dolichenus, Hrsg. T. Sarnowski, O.Ja. Savelja, Warschau 2000, s. 191-196.

Ŝeglov A.N., Frakijskie posvâtitel'nye reliefy iz Hersonesa Tavričeskogo [w:] Drevnie Frakijcy v Severnom pričernomore, red. T.D. Zlatkovskaâ, A.I. Melûkova, „Materialy i issledovaniâ po arheologii SSSR" 1969, nr 150, s. 135-177.

Solomonik È.I., Dve slučajnye epigrafičeskie nahodki v Krymu, „Numizmatika i épigrafika" 1965, nr V, s. 97-102.

Solomonik È.I., Latinskie nadpisi Hersonesa Tavričeskogo, Moskva 1983.

Solomonik È.I., Novye èpigrafičeskie pamâtniki Hersonesa, Kiev 1964.

Tomas A., Canabae legionis I Italicae. State of Research on Civil Settlements Accompanying the Legionary Camp in Novae (Lower Moesia) Compared to Relevant Lower Danubian Sites, ,Światowit” 2011 (2012), nr IX (L)/A, s. 155-168.

Tomas A., Living with the Army, Civil Settlements near Roman Legionary Fortresses in Lower Moesia, Warsaw 2017.

Zubar' V.M., Rimskaâ krepost' Haraks, „Stratum Plus” 2000, nr 4: Vremâ velikih migracij, s. $176-200$. 
Zubar' V.M., Rimskoe voennoe prisutstve v Tavrike, „Stratum Plus” 2001-2002 (2003), nr 4: Na okrainah antičnogo mira, s. 8-179.

Zubar' V.M., Sarnovskij T., Novaâ stroitel'naâ nadpis's Aj-Todora i nekotorye voprosy rimskoj voennoj organizacji v Tavrike vo vtoroj polovine II v. n.è., „Vestnik drevnej istorii” 1997, nr 4 (223), s. 50-59. 